\title{
Reading Robinson Crusoe from the lens of Islamic Utopianism
}

\author{
Morteza Yousofi (Corresponding author) \\ School of Language Studies and Linguistics, National University of Malaysia (UKM) \\ 43600 Bangi, Selangor \\ Tel: +60126687502 E-mail: mortezayusofi@yahoo.com \\ Ruzy Suliza Hashim \\ School of Language Studies and Linguistics, National University of Malaysia (UKM) \\ 43600 Bangi, Selangor \\ Tel: +60389216481 E-mail: ruzy@ukm.my \\ Mohd Faizal Musa \\ Institute of the Malay World And Civilisation (ATMA) \\ 43600 Bangi, Selangor \\ Tel: +603 89215280 E-mail: mfaizalmusa@ukm.my
}

Received: 01-11-2013

doi:10.7575/aiac.ijalel.v.3n.2p.187
Accepted: 23-12-2013

Published: 01-03-2014

URL: http://dx.doi.org/10.7575/aiac.ijalel.v.3n.2p.187

\begin{abstract}
The need for perfection is an innate feeling in all human beings and a broader sense of it would be people's craving to make a utopian society. Utopianism is rooted in religions like Islam, Christianity, Judaism and Hinduism. It is also discussed in many Western works trying to depict an ideal society like Plato's The Republic and More's Utopia. The utopian features raised by them are illustrated in many literary works and utopian fictions as is the case with Daniel Defoe's Robinson Crusoe. This paper attempts to analyze some common Western utopian features presented in Robinson Crusoe and compare them with Islamic traditions which describe the golden era of the Messiah of Islam. By referring to two utopian features of economic prosperity and spirituality, the essay concludes that the discipline of comparative literature provides an opportunity to compare literary works with discussions on Islamic studies and although Robinson Crusoe is set in a Christian context, it has some features in common with the Islamic Utopia.
\end{abstract}

Keywords: utopian fiction, Robinson Crusoe, theology, Islamic literature, comparative literature, messiah, utopia, Islamic messianism

\section{Introduction}

In this paper, we compare the novel, Robinson Crusoe, with the discipline of theology. Such an undertaking falls within the paradigm of Comparative Literature. To undiscerning scholars, the term "comparative literature" may denote the idea of choosing a piece of literary work of one geographical boundary and comparing it with another work of literature from other geographical demarcation which are similar in one way or another. However, the scope of comparative literature is broader than making a comparison within the field of literature alone. Henry H.H Remak, a prominent scholar in the field of comparative literature, believes that comparative literature should not be misunderstood as a discipline that compares literature of nations only but it is also a discipline that allows us to compare literature with other fields in humanities (Stallknecht \& Frenz, 2012). Remak's view was supported by The Greene Report in 1975 as a group of scholars under American Comparative Literature Association stressed that: "Comparative Literature movement wanted to explore the relationships of literature with the other arts and humanities: with philosophy, history, history of ideas, linguistics, music, art and folklore among others" (Bernheimer, 1995, p. 28). The above discussion provides an avenue for comparatists to compare religion with literature which is the thrust of this essay where we shall compare the idea of Islamic utopia with Robinson Crusoe.

The idea that every human being aspires to gain a better life and eagerly tries to reach perfection is an undeniable fact. Indeed, the issue of reaching perfection is an innate fact which is instilled in every human being. The great efforts of scholars and scientists who devote their whole life for inventing new tools or discovering new ways of making human life easier are examples of this claim. The painstaking efforts of businessmen and those who are more inclined to prosper financially are another example of people who move towards perfection and a better future. The difference lies in the fact that every single person may have a different concept of the idea of perfection in mind. Mujtaba Musawi Lari acknowledges the same idea in his book Ethics and Spiritual Growth:

Every human being that is born in this world, regardless of its individual or social circumstances, aspires to its own perfection in accordance with its innate nature and its inborn intellect. It puts up with all kinds of sufferings and hardships for its hope of a brighter future. Its starting point is deficiency and its movement is directed towards perfection. It grows and develops with every step forward on the path of perfection. Man's 
intellect and spirit give such a profundity, power and speed to his movement towards perfection that there is no time limit to it except eternity itself. (Lārīi, 1997)

Looking at the same idea from a broader perspective brings about the notion that a human being longs to make the society he is living in a utopian one. In other words, a person's effort is concentrated towards developing a better self at the individual level and then when it comes to the broader stage of society, everyone yearns for living in a utopian society. We contend that the idea of expecting a savior derives from the belief in utopianism which is an important facet in Robinson Crusoe. That is, there must be a savior who will come and rescue the world from tyrannies and injustices and to move the world towards its perfection. Therefore, the idea of utopianism and consequently believing in a savior to bring about that utopian society originates from human beings' conscience and common sense.

\section{Utopianism in Western philosophy}

Thomas More is an important figure with regards to utopianism, not only for his depiction of an ideal society in Utopia, but also because he coined the word in the first place. His book consists of two parts, namely Book One and Book Two. In the first part, Raphael Hythloday, a traveler who happens onto Utopia is introduced and the second book consists of his observations and discoveries there. In Book Two, Raphael gives a detailed account of Utopia, including its physical location and description, system of government, working conditions there, social arrangements and system of organization, travel facilities, education system, religion and other issues he observes in Utopia. More depicts an island in which there is no private ownership and where products are stored in warehouses, with people taking them according to their needs and no more, no less. As for the safety of such a place, it is enough to know that there are no locks on the doors there. The main priority of its inhabitants is agriculture and they are trained to do this from an early age. They lead a deliberately simple life in which people wear the same simple clothes and are quite thrifty. Everyone must work in this community except a select few. Women must also work and are subordinate to men.

The fact that the majority of the inhabitants must work does not mean that they are engaged in drudgery. Instead, the ultimate aim is to give its inhabitants enough time to cultivate their minds and this is regarded as the secret of a happy life. Priests are allowed to marry, and premarital sex and adultery are illegal and punishable by lifelong celibacy and enslavement. There exist many different religions in Utopia and all inhabitants are allowed to practice their religions. This idea of religious tolerance results in everyone respecting each other's religions and beliefs. The majority of the citizens believe in the immortality of the soul and the idea of reward and punishment in the hereafter. These were some of the features described in More's Utopia as the features of an ideal society.

While More have coined the word utopia, the idea of an ideal and perfect society existed far before that. Plato's The Republic is considered to have one of the earliest accounts of utopia. Plato discusses many issues in this book but his main focus is depicting an ideal society through the words of Socrates which can provide salvation for human beings. Plato analyzes the human psyche and divides the human soul into three parts namely reason, spirit and appetite; accordingly, people are divided into three groups: rulers, soldiers, and producers. In a just society, rulers must provide law while soldiers should submit to the rulers' orders and producers should accept such authority. The Cambridge Companion to Plato's Republic notes that the features of this ideal city are: "Communism of property, abolition of the family, tight control of every aspect of life by the philosophical ruling class, maximal "unity" of thought and feeling among the citizens" (Ferrari, 2007, p. 232). Therefore, although Plato depicted an ideal system in which some of the features of his ideal society are similar to that of More's, there are still some points of difference which may lead to the conclusion that utopian features are relative.

Thomas Hobbes, a contemporary of Defoe, published his own version of an ideal society called Leviathan in 1651 . The first thing Hobbes does in his book is to demonstrate how human life would be if people were left to their own devices and without a government. He believes that if there is no absolute force and sovereign to control human beings, everyone would reserve a right to do whatever he likes in order to gain more profit for himself. "In short, Hobbes is saying, a life without government is not worth living" (Newey, 2008, p. 1). His famous description of human life in the state of nature - or in other words, the state of war-is "solitary, poor, nasty, brutish, and short" (Hobbes \& Crooke, 1651, p. 78). Hobbes' main focus is on the importance of the foundation of a central government and authority in order to prevent disagreement and civil war as well as to maintain the peace of the nation.

Yet another person who has tried to depict an ideal political system is Jean-Jacques Rousseau who expressed his ideas on the ideal society in The Social Contract. Rousseau believed that liberty can be acquired when people act as a collective in making laws and since they may not, at times, know their "real will", they must have a guide and leader to overrule people's conventions and values. Should anyone break the rules, his punishment according to the law would not be considered the restriction of his liberty. And it is in the light of this law that man can dispatch himself from the state of nature and go forward to the direction of civil society.

More's utopian features encompass the personal and communal practices but the notion of what utopianism constitutes is relative; that is, what is regarded as a utopian feature for one scholar may not be considered so by another. This is the reason why utopias are depicted differently and in some cases contradictorily. Plato, Hobbes and Rousseau were fellow philosophers who contributed to their notions of utopia. Although there were other philosophers and thinkers who engaged in this debate on utopia, the three we have illustrated above show various trajectories which they consider as features of perfection. It is beyond the scope of this paper to cover in depth other points of view and compare them to More's initial idea. 


\section{Utopianism and Messianism in religions}

The concepts of utopianism and seeking perfection and consequently, the idea of messianism are also the focus of attention in different religions. In fact, writing comprehensively about messianism in different religions requires a vast amount of literature and we will just touch upon some major ideas in this regard in Islam, Hinduism, Christianity and Judaism. This vast amount of discussions about the idea of utopianism clearly shows the originality and importance of this discussion.

\section{Utopianism in Islam}

There are clear statements and glad tidings in both Koran and traditions-which are two major sources of Muslims' beliefs - which stipulate to the coming of a savior - a messiah — who will then bring about a utopian society. Sayyed Sadruddin Sadr has compiled a book titled Al-Mahdi (a.s.) which is about the Messiah in Islam. There are numerous traditions and detailed descriptions of the Messiah in Islam, his disposition, his looks, his character, and his plans when he reappears. The following are selected traditions that prophesy his reappearance after his occultation:

'The author of "Esa' af-ur-Raghebeen" (on page 148) narrates from Hakim (from the book of Sahih) who narrates from the Messenger of Allah (S.A.W.A.) as such: At the end of time, a severe calamity shall overtake my nation ... Allah will send a man from my progeny or he said: from my Ahl-e-bayt who shall fill the earth with equity and Justice' (Ișfahānī, 1994, p. 164).

The Messiah's name in Islamic traditions is mentioned as "Mahdi" and his features are clearly described. Therefore, as the Messiah's first name suggests, a more clear term for Islamic Messianism may be Mahdism. The author of "Yanabiul-Muwadda" narrates from the author of "Fara'ed-ul-Semtain" who narrates from Ali-ibn-Hallal who narrates from his father that the Holy Prophet (S.A.W.A.) said: "Mahdi will come at the end of time and will fill the earth with equity and justice just as it was previously filled with cruelty and oppression" (Ișfahānī, 1994, p. 164). According to the traditions mentioned above, the Messiah of Islam whose name is Mahdi will come at a time when cruelty and oppression is everywhere and he will come to eradicate injustice and sow the seeds of equity and justice.

Hashim al-Bahraani has examined more than 130 verses of the Holy Quran in his book The Qa'em in the Qur'an that are specifically about the Messiah of Islam and the meaning of each verse has been elaborated by relevant traditions.

The verse number 105 in Al-Anbiyaa writes as such:

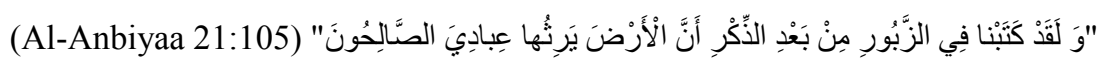

The literal translation of the above verse is: "Verily We did write in the Psalms after the reminder (Torah): 'My righteous servants shall inherit the earth" (21:105). The tradition elaborating on this verse is narrated from Imam Sadiq who says: "Verily We did write in the Psalms after the reminder (Torah): "My righteous servants shall inherit the earth" (21:105). Allah has mentioned (this) in all of His Books. "The righteous servants" are the Qa'em and his companions" (Al-Bahraani, 2006, p. 146). The Koranic verses and traditions clearly state that there would come a period of time when the Messiah of Islam whose name is Mahdi will appear and will rule the earth along with his companions and these people are the righteous people.

\section{Messianism in Hinduism}

According to Dr. Malika B. Mistry's paper on universality of the Mahdism doctrine, there is the idea of awaiting a savoir in Hinduism as well. In their idea, the era before the end of the world is called Kalyug and that era has already started. They are waiting for their Messiah called Kalki who is supposed to "lead the India to glory" (Mistry, 2007). He will also do away with tyranny and injustice and due to his goodness and efforts, Indian religion would prevail the world and India would become master of all nations.

\section{Messianism in Judaism and Christianity}

The idea of the advent of a messiah and subsequently, making a utopian way of life is also quite prevalent in Judaism and Christianity. We would like to refer to this eschatological hope which permeates the biblical scripture and to divide it into two stages of the time before Christ and during his life.

\section{Before Christ's birth}

A concise history of Prophet Abraham's progenies would be helpful in better understanding the messianic discussions in Judaism and Christianity. According to Dr. David Shenk's article called Messianic Hope in Biblical Eschatology, Prophet Abraham had two sons called Isaac and Jacob whose descendants were called Israel. They were freed from the tyrannies of Pharaoh by Prophet Moses and were divided into two groups of Northern Kingdom (Israel) and Southern Kingdom (Judah) after Prophet Solomon's demise. The Northern Kingdom of Israel was taken by Assyrians in 722 B.C. and the Davidic monarchy fell in 586 B.C. Almost all of Israel was forcibly taken to Babylon and spent 70 years in Exile which has seemingly been a difficult time for them. It is quite common for people who believe in and are aware of religious prophecies about saviorism and utopianism to recall the promised prophecies of freedom and relief in times of great distress and Israel was not an exception. Messianic hope was flourishing during seventy years of Exile and prophets "exhorted the people with the promise of the coming Messiah, who would inaugurate peace and justice among the nations" (Shenk, 2007). The following is a proclamation of Prophet Isaiah when the Northern Kingdom was under attack by Assyrians:

A shoot will come up from the stump of Jesse (He is the father of David. This refers to the promise that a son of David will rule forever.)

From his roots a Branch will bear fruit. 
The Spirit of the Lord will rest on him-

The Spirit of wisdom and of understanding,

The Spirit of counsel and power,

The Spirit of knowledge and of the fear of the Lord-

And he will delight in the fear of the Lord.

He will not judge by what he sees with his eyes,

Or decide by what he hears with his ears;

But with righteousness he will judge the needy,

With justice he will give decisions for the poor of the earth.

He will strike the earth with the rod of his mouth;

With the breath of his lips he will slay the wicked,

Righteousness will be his belt

And faithfulness the sash around his waist....

They will neither hurt nor destroy in all my holy mountain,

For the earth will be full of the knowledge of the Lord

As the waters cover the sea.

In that day the Root of Jesse will stand as a banner for the peoples;

The nations will rally to him, and his place of rest will be glorious.

(Isaiah 11:1- 5; 9 - 10)

The excerpt prophecies the advent of a savior and his features like the just way he judges, the justice he has and the knowledge he spreads.

During Christ's lifetime:

The context in which Jesus was born was a context of high messianic expectation since after seventy years of Exile, some of Israelites returned to Canaan and rebuilt the Temple and Jerusalem. Jesus began his divine duties among his nation when he was thirty and it lasted just for three years when he was ascended to heavens as Muslims believe or was crucified as is the belief of the Christians.

Al-Haashemi cites from the New Testament and proves that the main concern and major duty of Jesus Christ was to inform people that the kingdom of God-_ملكوت خدام- will begin soon. Consequently, people wanted to prepare themselves for the coming of the kingdom of God and began to acquire a manner of awaiting. Jesus made it clear that the kingdom of God would be universal. His saying that

"و از مشرق و مغرب و شمال و جنوب آمده در ملكوت خدا خواهند نشست" (Al-hashemi, 2006, p. 148).

"All from the east, west, north and south would come and would be under the kingdom of God" shows the universal scope of the kingdom of God. Jesus talks about the return of "بֶّر انسان" —son of man —and the Christians believe that this person is Jesus himself while Al-Haashemi assures in his book that it cannot be so (p. 164). Rather, by "son of man" Jesus meant Muslim's Messiah who is Mahdi. He also cites several statements from the Bible concerning Jesus return like:

$$
\text { "شنيده ايد كه من به شما كفنت: مى روم و نزد شما مى آيم ..." (p. 145) }
$$

It means that Jesus told his students: "I have told you before that I will go and then will come back to you..." In the former example, Jesus refers to the return of a messiah and in the latter, he confirms his own return. As stated before, the Jews had heard about the coming of a messiah from Moses and were again hearing about the kingdom of God from Jesus who was discrediting them. That is, on the one hand, Jesus was informing the Jews of the same fact-coming of the kingdom of God - they had heard from Moses. The Jews knew that the kingdom of God is approaching and they hoped that the leader of this movement would rise out of themselves. On the other hand, Jesus was not a Jews advocate and was even criticizing them and gained some followers as well. Therefore, they became hostile towards Jesus; so much so that they arrested him and after a trial session, assigned the death sentence for him. He informed his disciples that he would be killed but his disciples objected claiming that it is not possible for the Messiah to be crucified. After the crucifixion of Jesus, he was resurrected and met his disciples and when he was about to ascend, two angels appeared and told the disciples: "This same Jesus who has been taken from you into heaven, will come back in the same way you have seen him go into heaven"' (Shenk, 2007). It is important to note that there is a difference of opinion between Muslims and Christians in that Muslims believe that according to Koran, Jesus was not crucified; they mistakenly killed someone else.

Al-Haashemi states that Muslims believe that Jesus is preserved in heavens and it is around two thousand years since his ascent. Since the whole idea is a unique one, there must be an important goal in his return and that would be his share in running the kingdom of God when the Muslims' Messiah returns. The features of the kingdom of God which are stated in the Bible are almost the same as the ones stated in Muslims' traditions. It would be a just kingdom in 
which there would not be any oppression and tyranny; nor would be any poverty and destitution. It would be like a little day of judgment before the hereafter in which people will receive worldly rewards and we will refer to the Muslims' traditions on this issue later in this article.

\section{Utopianism and messianism in Western literary works and in Robinson Crusoe}

The idea of utopianism and believing in the advent of a messiah which is expressed in Western philosophy as well as in different religious doctrines is also reflected in various Western literary works. This idea is so rampant in literary works that a unique literary genre is developed which is called "utopian literature". So far, more than one thousand and four hundred utopian works have been published in English language alone which signifies the importance of such a genre and also the significance of this idea (Sargent, 1976). Daniel Defoe published a novel called Robinson Crusoe in 1719 which is a fictional autobiography of the hero of the novel who is an ambitious young boy and is cast away on an island and spends twenty eight years before being rescued. This novel became so popular that the literary genre of "Robinsonade" was coined to refer to its numerous imitations. It is important to note that Jean-Jacques Rousseau who was an eminent $18^{\text {th }}$ century philosopher has tried to devise an educational system for the natural man to survive in a corrupt society and has expressed his views in his book Emile. He states that Robinson Crusoe is the best source "on an education according to nature" (Rousseau, Kelly, \& Bloom, 2010, p. 100). Rousseau suggests that Robinson Crusoe is the first book Emile has to read in a long time. It serves a noble position for Emile as it is always read with delight and gusto. He believes that Robinson Crusoe, who could save himself in spite of being marooned on a deserted island, would interest people of different ages. Emile should take this example to apply to other situations. He should put himself in Crusoe's shoes, examine his conduct in different situations and try to avoid his mistakes. As we have stated earlier in this paper, utopian features are relative and are different from the perspective of one scholar to another. The aspect of relativity of utopian features gives birth to the creation of utopian depictions in literary works which are sometimes viewed by different readers to be in contrast with one another. These differences relate to different ways of conceptualizing utopianism as we have illustrated earlier in this paper. However, Robinson Crusoe can be regarded as a utopian novel and it, indeed, includes utopian criteria as Niu Hongying discusses in the article entitled Robinson Crusoe and utopian thought of the West (Niu, 2007). In other words, it is essential to note that Crusoe may not be a Messiah in the full sense of the word and this paper is not trying to prove that; however, our emphasis is to highlight two utopian features and compare them to the same ideals in the era of the Messiah of Islam.

\section{Spirituality in Robinson Crusoe}

Belief in God and worshipping Him is a utopian feature mentioned in some utopias like the one in More's. Most people in the Utopia as depicted by More believe in the existence of a creator who is called "God" by Robinson Crusoe. Although there are several different religions in Utopia like sun worship, moon worship, and planet worship, the majority of its inhabitants believe in divine unity; that is, the existence of "a single divine power, unknown, eternal, infinite, inexplicable, and quite beyond the grasp of the human mind, diffused throughout this universe of ours, not as a physical substance, but as an active force" (More \& Turner, 2003, p. 117). The main twist in Crusoe's life which greatly affects the other parts of his activities is the spiritual awareness he finds. His belief in God as the absolute omnipotent loosens him from the disadvantages of the lack of society he faces in the island. He trusted God so much that he was not even afraid of death in the scene of confronting the mutineers and even comforted the captain by saying that "we ought to expect that the consequence, whether death or life, would be sure to be a deliverance" (Reference, 2006, p. 246). He had found a sort of relief in his spiritual and lonely relationship with God. He was savoring his private moment of prayer; so much so that it led him to confess that he "will find deliverance from sin a much greater blessing than deliverance from affliction" (Reference, 2006, p. 91). He has found peace and calmness in praying and communicating with God. His praying has had so many other benefits for him. He was able to tolerate loneliness for a long time and was not depressed. His patience and diligence has to do with his prayers. In fact, he gains his high spirits through prayer. Crusoe is the epitome of industry and perseverance. This feature is one of the main ideas behind a utopian society. The question is what makes Crusoe so active and hardworking? Novak states that "Religion is part of Crusoe's life. It gives him a rationale for what he is already doing in striving to survive" (Novak, 1983, p. 44). George Starr believes that what pushes Crusoe and is the key to his vitality is in fact prayer and his belief in Providence as well as his dependence "upon divine support and protection" (Starr \& Defoe, 1971, p. 118). Crusoe was full of hope after his conversion and it allowed him to continue with his adventures on the island, leading an active life which was free from lethargy, slothfulness, and laziness of any kind. With the help of this hope which was of course rooted in his belief in the hereafter and in his Creator, he could survive. Hence, the major source of Crusoe's survival, in spite of all the problems he faced in the island, can be rooted to the spiritual aspect of his life.

\section{Spirituality in the era of the Messiah of Islam}

Believing in the unity of God as well as a general spiritual spirit in the society is a feature of the Messiah of Islam's era. The following verse had been repeated in Quran three times:

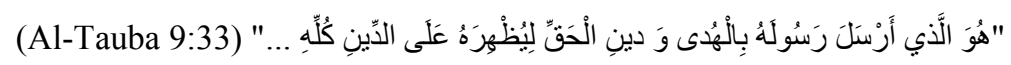

"He is the One who sent His messenger with guidance and the system of truth, to make it expose all other systems...". In spite of all the great efforts of Prophets, Islam is not yet accepted by all people unanimously. According to some traditions, Islam would permeate wherever night passes through and there would not be polytheism on the face of the earth when the Messiah of Islam reappears (Majlisī, 1983a, p. 55) . It is important to note that the universality of Islam during the Messiah of Islam's age would surely be due to its truth and authenticity which will become more apparent 
and clear by the Messiah's enlightening explanations and by his unique way of clarification. This universal belief in God which would be fulfilled during His era would lead to the foundation of a universal government. Under the light of the belief in monotheism and more specifically the belief in Islam, people would come to accept laws which are based on that; consequently, their individual and societal relations would be based on the criteria which are themselves rooted in Islamic doctrines. When read from the Islamic perspectives, the belief in God and trusting him which have been depicted in Robinson Crusoe proves to be the source of the hero's great achievements. Since our creator is aware of our needs and welfare and it is Him who has devised Islam as the complete guideline for human being, there would not be any doubt that following Islamic principles would lead to human being's perfection and prosperity. It is the comprehensive belief in real Islam and following its orders that can make a society an ideal one in all respects as is depicted in our traditions for the era of the Messiah of Islam.

\section{Economy in Robinson Crusoe}

Economic issues in Robinson Crusoe are of utmost importance and, as Novak puts it, most of Defoe's works contain some kind of "economic speculation" and Robinson Crusoe is not an exception (Novak, 1963, p. 474). Division of labor for Utopians is an economical key of success as depicted in More's Utopia. The same feature exists in Robinson Crusoe in which Crusoe does not exempt himself from work in spite of having Friday as his slave. Rees supports this idea by stating: "Although he trains Friday so that he can take over, it is clear that they cooperate in skilled work, and that Crusoe continues to do his share" (Rees, 1996, p. 89). It is important to note that spirituality prevails in his other motivations after his conversion. For instance, in terms of economy, he would be better off treating Friday like a slave and asking him to work harder, but, on the contrary, he works together with Friday himself. Economists have seen Crusoe as an economic figure and it is interesting to know that Defoe regarded himself as an expert on the economic problems of England as well (Novak, 1963). Novak believes that Defoe was prepared to create an economic utopia on the island by means of three things: an ideal setting, the right man, and a certain quantity of tools (Novak, 1963, p. 480). An ideal milieu for Crusoe which consists of a fertile land and a warm climate is prepared in the island which could enable him to have abundant resources. The second element Novak believes Defoe utilized to create an economic utopia on the island is "the right man". As travel literature shows, people who are left alone on an island usually perished from despair. Crusoe, the Spaniard, and the captain were all in a state of despair at the very beginning of their life on the island; so much so that Crusoe called the island "the island of despair". But 'refusing to succumb to despair, Crusoe uses his "instinct of workmanship" to recreate on his island the level of economic existence which he had known in England and Brazil' (Novak, 1963, p. 479). The third feature with which Defoe planned to bring about an economic utopia was a sufficient amount of tools. Crusoe could not perform as well as he did without the carpenter's chest he salvaged from the wreck. He believed that without his tools, he would have lived like a "meer Savage" if ever he could manage to live: "How I could not have so much as got any food, except fish and turtles; and that as it was long before I found any of them, I must have perished first. That I should have lived, if I had not perished, like a meer savage. That if I had killed a goat, or a fowl, by any contrivance, I had no way to flea or open them, or part the flesh from the skin, and the bowels, or to cut it up; but must gnaw it with my teeth, and pull it with my claws like a beast" (Reference, 2006, p. 123).

In spite of the fact that Crusoe's tools are of high value, the knowledge and civilization which he possesses in his mind is regarded as even more important than his tools. Rees refers to the same fact mentioning that though his tools do help him rescue him from a state of nature, "its true legacy is the knowledge imprinted, however imperfectly, on his brain. He has to know how to use the arms and tools. With that knowledge comes the capacity to fulfill the opposite half of the Aristotelian formula. Instead of acting like a beast, he now has the potential to act like a god-within limits" (Rees, 1996, p. 79). Crusoe, therefore, was able to bring about an economic utopia by making good use of the fertile land and suitable climate, his instinct and his tools.

\section{Economy in the era of the Messiah of Islam}

There would be an economic utopia and welfare during the Messiah of Islam's golden age as are depicted in traditions. Since he would go according to Islamic laws on economy, he would be able to create a prosperous society and the fruit of such economy during the Messiah of Islam's age is stated in Islamic traditions. In his time, there would be unprecedented blessing in the world in a way that the earth will throw up its bounties and the skies will shower their mercies (Majlisī, 1983b, p. 128). The earth would toss up its treasures; mercy will rain from the skies; trees will be loaded with flowers and the earth will manifest its greenery (Majlisī, 1983c, p. 316); the Messiah would dole out incomputable wealth. At that time, economic welfare will attain such heights that no one can be found to be eligible for zakat which is an Islamic tax given to the poor (p. 339). In terms of increase in knowledge at the era of Islam's Messiah, it is surprising to know that traditions have considered the knowledge to be twenty seven alphabets and just two of them would be revealed before His advent. Twenty five alphabets of knowledge would be disclosed during his government (p. 336). Of course when people get a higher knowledge, it would affect on their economy as well. Not only would the high knowledge of human being affect their economy, but also it would be manifested in all other areas of life. The general hygiene would improve so much that longevity would be commonplace (p. 330). According to Islamic traditions, the world would be quite safe in a way that people will not be afraid to lose their lives or wealth from maneating, wild and carnivorous beasts (p. 385). All in all, the intellects of the people will be perfected and their morals will attain completion (p. 328). The world would be so developed in all aspects and justice would be so widespread that even the dead would crave to be alive again to enjoy the bounties of His rule. Therefore, the era of the Messiah of Islam would be an ideal era in all respects including economic issues. 


\section{Conclusion}

The importance of the fundamental idea of utopianism and subsequently, the hope for coming of a messiah to make that utopia a reality in real life is quite tangible as argued in this article. It is an important doctrine in various religions around the world. These ideas are reflected in literary works and we have shown how some of the notions of perfection in Islam can be found in Robinson Crusoe. Although Crusoe is a Christian, the aspects that Defoe describes and are discussed in this article are closely aligned to Islamic messianic vision which in turn shows the significance of these two features in bringing about a utopian society. No other scholars, prior to this, have made a connection between Robinson Crusoe and Islamic utopianism; however, through the discipline of comparative literature, we were able to compare this literary work with the discipline of Islamic studies and provide examples where features of Islamic Utopia are inherent in Robinson Crusoe. Further comparative studies involving canonical texts with other disciplines can reveal similarities and differences of trajectories important to comparative scholars. By looking at these classical texts with new lenses, different shades of understanding will come to light.

\section{References}

Al-Bahraani, S.H. (2006). The Qaem in the Quran: Shiabooks.ca.

Al-hashemi, B. (2006). Monjee Beh Revaayat-E-Eslaam Va Maseehiat [Saviour, as narrated by Islam and Christianity] (M. Ehteshaaminia, Trans. S. A. Razavie Ed.). Tehran: Afagh.

Bernheimer, C. (1995). Comparative Literature in the Age of Multiculturalism: Johns Hopkins University Press.

Ferrari, G.R.F. (2007). The Cambridge Companion to Plato's Republic: Cambridge University Press.

Hobbes, T., \& Crooke, A. (1651). Leviathan Or The Matter, Form, and Power of a Common-wealth, Ecclesiastical and Civil: Andrew Crooke.

Iṣfahānī, Ș.D.Ṣ. (1994). Al-Mahdī (A.S.): Naba Organization.

Lārī, M.M. (1997). Ethics and Spiritual Growth: Foundation of Islamic Cultural Propagation in the World.

Majlisī, Muḥammad Bāqir ibn Muḥammad Taqī. (1983a). Bihar al-anwar [The Seas of Lights] (Vol. 51). Beirut: AlWafa Foundation Beirut.

Majlisī, M.B. (1983b). Bihar al-anwar [The Seas of Lights] (Vol. 23). Beirut: Al-Wafa Foundation Beirut.

Majlisī, Muḥammad Bāqir ibn Muhammad Taqī. (1983c). Bihar al-anwar [The Seas of Lights] (Vol. 52). Beirut: AlWafa Foundation Beirut.

Mistry, M. B. (2007). Universality of the mahdism doctrine its implications for a unified and just world. Retrieved 5 February 2012, 2012, from http://www.mahdaviat-conference.com/vdcd250o6yt05.mey.html

More, T., \& Turner, P. (2003). Utopia: Penguin Books Limited.

Newey, G. (2008). Routledge Philosophy Guidebook to Hobbes and Leviathan: ROUTLEDGE CHAPMAN \& HALL.

Niu, H. Y. (2007). Robinson Crusoe and utopian thought of the West. Foreign Literature Studies, 29(5), 84-89.

Novak, M. E. (1963). Robinson Crusoe and Economic Utopia. The Kenyon Review, 25(3), 474-490.

Novak, M. E. (1983). Realism, myth, and history in Defoe's fiction: University of Nebraska Press.

Rees, C. (1996). Utopian imagination and eighteenth-century fiction: Longman.

Reference, I. (2006). Robinson Crusoe: Webster's Thesaurus Edition: Lightning Source Incorporated.

Rousseau, J.J., Kelly, C., \& Bloom, A.D. (2010). Emile, Or, On Education: Includes Emile and Sophie, Or, The Solitaries: Dartmouth College Press.

Sargent, L.T. (1976). Themes in Utopian Fiction in English Before Wells. Science Fiction Studies, $275-282$.

Shenk, D. W. (2007, 12th Nov 2007). Messianic Hope in Biblical Eschatology. Retrieved 5th February 2012 , 2012, from http://www.mahdaviat-conference.com/vdcjfxexzuqem.29u.html

Stallknecht, N.P., \& Frenz, H. (2012). Comparative Literature: Method and Perspective: Literary Licensing, LLC.

Starr, G.A., \& Defoe, D. (1971). Defoe and Spiritual Autobiography: Gordian. 